Original Contribution

\title{
EFFECT OF DIETARY INCLUSION OF RÜMANOL ML VEGETABLE FAT ON FATTENING HYBRID TURKEY BROILERS
}

\author{
M. Lalev, N. Mincheva*, P. Hristakieva, M. Oblakova
}

Agricultural Institute, Stara Zagora, Bulgaria

\begin{abstract}
The effect of substitution of dietary sunflower oil with vegetable fat Rümanol ML in compound feeds of turkey broilers on production and slaughter traits was investigated. To this end, two groups with 75 male broiler turkeys, one day-old, with equal body weight were formed (control and experimental) and reared throughout 16 weeks. Six-phase feeding was applied-starter I (0-3 week), starter II (4-6 week), starter III (7-8 week), grower I (9-10 week), grower II (11-12 week) and finisher (13-16 week). During those periods, the control group was fed rations with sunflower oil content of $3 \%, 4 \%, 5 \%, 7 \%$ and 8 $\%$, respectively, whereas the experimental group-rations with feed fat Rümanol ML at the same amount as sunflower oil.

The results from the experiment demonstrated that Rümanol ML used as alternative of dietary sunflower oil in turkey broilers feeds had a positive effect on the live weight during the finisher period and the weight gain throughout the entire rearing period manifested by statistically significant increase by $7.13 \%$ and $7.17 \%(\mathrm{p}<0.001)$ respectively and improved feed conversion by $2.5 \%$. Slaughter analysis showed higher absolute values of the grill weight by $9.8 \%$ and of breast by $10.28 \%$ and no effect on slaughter yield and the share of valuable cuts (breast, legs, wings). The integral evaluation of replacing sunflower oil in compounds feeds for turkey poults with feed fat Rümanol ML on the basis of EPEF showed better performance by $16.64 \%$.
\end{abstract}

Key words: turkey broilers, sunflower oil, vegetable fat Rümanol ML, growth performance, slaughter traits

\section{INTRODUCTION}

Fat is the high-energy component of poultry rations. Supplementation of fat to compound feeds improves their physical characteristics through reduction of dusting and increase in energy density. Fat is also a source of essential fatty acids (1) and enhance the absorption of fat-soluble vitamins (2). In general, vegetable fat has a better absorption and higher metabolisable energy due to the high content of unsaturated fatty acids than animal fats and therefore, are utilised more efficiently by birds (3).

The main vegetable fat used in poultry nutiriton in Buglarian is sunflower oil. Data provided by the Union of vegetable oils and oily products state that it contains 55-75\% essential fatty acids and 15-25\% saturated

\footnotetext{
*Correspondence to: N.S. Mincheva, Agricultural Institute-Stara Zagora, Bulgaria, E-mail: minchevan@yahoo.bg
}

fatty acids. Other sources of vegetable fat are rapeseed, flaxseed, soybean, coconut and palm oil. The most important differences among the different vegetable oils comprise their fatty acid profile. For instance, apart polyunsaturated fatty acids, coconut and palm oils contain also other saturated fatty acidslauric, myristic, palmitic. Balevi and Coskun (4) reported differences in the fatty acid composition of six vegetable oils and established highest content of linoleic acid and lower content of linolenic acid in sunflower oil, resulting in $n-3 / n-6$ PUFA ratio close to zero.

The main goal of broiler production is achieving higher yield of breast meat, less abdominal fat and improved feed conversion (5). Poorghasemi et al. (6) affirmed that the type of fat influenced considerably the weight, weight gain, feed conversion, yields of breast and thigh meat and abdominal fat content in broiler chickens, but not slaughter yield and 
LALEV M., et al.

relative weights of visceral organs. Other comparative studies have shown that the utilisation of various oils as olive, sunflower, rapeseed, flaxseed in poultry diets had no effect on the growth (7-10). The opinions on the effect of fat source on feed conversion are contradictory. Earlier reports of Pinchasov and Nir (11) and Zollitsch et al. (12) provide information for better feed conversion with higher dietary polyunsaturated fatty acids content. According to Sanz et al. (13) and Abas et al. (14) the fat type did not influence feed conversion in broiler chickens, confirmed also by Jankowski et al. (15) in an experiment with turkey broilers.

Abdominal fat is highly sensitive to changes in the dietary fatty acid profiles and is accpeted as indicator of body fat of poultry (13). Experiments have shown that the use of sunflower oil was efficient in the reduction of body fat deposition due to its high content of polyunsaturated omega- 6 fatty acids (13). The authors affirmed that the energy of unsaturated fat could be used for other metabolic purposes while the energy from saturated fat sources was used more rarely and was accumulated as body fat. Crespo and Esteve-Garcia (16-17) established that chickens fed rations supplemented with sunflower or flaxseed oil had significantly lower abdominal fat percentage than birds fed feed with animal fat or olive oil. Ayed et al. (18) reported higher abdominal fat percentages in broiler chickens fed rations with palm oil, which was rich in saturated fatty acids.

A study on the physiological effect of inclusion of soybean, flaxseed and rapeseed oils with various $n-6$ and $n-3$ fatty acids ratios in turkey poults diets demosntrated no differences in slaughter yield and breast, thigh and drumstick meat yields (15).

At the background of the global deficiently of foods, the issue of utilising functional mixtures of various vegetable oils as alternative source of energy for poultry diets is especially important. Therefore, our study aimed to evaluate the effects of replacing dietary sunflower oil with the feed fat Rümanol ML in compound feeds for turkey broilers on their productive and slaughter traits.

Table 1. Composition and nutritional value of compound feeds

\begin{tabular}{|l|c|c|c|c|c|c|}
\hline \multirow{2}{*}{ Ingredients, \% } & \multicolumn{6}{|c|}{ Periods, weeks } \\
\cline { 2 - 6 } & Starter I & Starter II & Starter III & Grower I & Grower II & Finisher \\
& $1-3$ & $4-6$ & $7-8$ & $9-10$ & $11-12$ & $13-16$ \\
\hline Wheat & 44.56 & 45.75 & 50.93 & 51.53 & 60.01 & 63.68 \\
Soybean meal & 36.00 & 34.00 & 30.00 & 28.50 & 21.00 & 19.00 \\
Fish oil & 7.00 & 6.00 & 4.00 & 3.00 & 2.00 & - \\
Sunflower oil / Rümanol & 3.00 & 4.00 & 5.00 & 7.00 & 7.00 & 8.00 \\
ML & & & & & & \\
Sunflower meal & 4.00 & 5.00 & 5.00 & 5.00 & 5.00 & 5.00 \\
Lysine & 0.30 & 0.30 & 0.30 & 0.30 & 0.30 & 0.30 \\
Methionine & 0.14 & 0.15 & 0.12 & 0.12 & 0.14 & 0.12 \\
Salt & 0.25 & 0.25 & 0.25 & 0.30 & 0.30 & 0.30 \\
Dicalcium phosphate & 3.10 & 2.90 & 2.75 & 2.60 & 2.60 & 1.90 \\
Limestone & 0.60 & 0.60 & 0.60 & 0.60 & 0.60 & 0.70 \\
Premix & 0.50 & 0.50 & 0.50 & 0.50 & 0.50 & 0.50 \\
Mycofix & 0.20 & 0.20 & 0.20 & 0.20 & 0.20 & 0.20 \\
Salgard & 0.20 & 0.20 & 0.20 & 0.20 & 0.20 & 0.20 \\
Optizyme & 0.10 & 0.10 & 0.10 & 0.10 & 0.10 & 0.10 \\
Cycostat & 0.05 & 0.05 & 0.05 & 0.05 & 0.05 & - \\
ME, kcal/kg & $2846 / 2845$ & $2910 / 2908$ & $2995 / 2993$ & $3121 / 3118$ & $3166 / 3163$ & $3255 / 3252$ \\
Crude protein, \% & 28.05 & 26.86 & 24.05 & 22.07 & 19.28 & 17.27 \\
Lysine, \% & 1.75 & 1.66 & 1.46 & 1.37 & 1.14 & 1.00 \\
Methionine, \% & 0.60 & 0.59 & 0.50 & 0.48 & 0.44 & 0.38 \\
Calcium, \% & 1.41 & 1.33 & 1.23 & 1.15 & 1.11 & 0.90 \\
Available phosphorus, \% & 0.81 & 0.75 & 0.68 & 0.63 & 0.61 & 0.45 \\
\hline
\end{tabular}

\section{MATERIALS AND METHODS}

The experiment was conducted in the experimental base of the Agriculture Institute - Stara Zagora with 150 day-old male broiler turkeys divided in two groups: control and experimental (75 birds in each) with equal body weight. They were reared on a wooden shavings litter with free access to feed and water for 16 weeks. Two dietary fat sources were used. Controls received a wheat-soybean 
diet with sunflower oil, and the experimental group: wheat-soybean diet with the same proportion of Rümanol ML instead of sunflower oil. The feed fat Rümanol ML is manufactured by Rübelmann, Viernheim, Germany and consists of a mixture of vegetable oils from rapeseed, sunflower, coconut, palm and shea with total linoleic value of $20-25 \%$ and the following fatty acids distribution: $28 \%$ saturated, $43 \%$ monounsaturated and $28 \%$ polyunsaturated fatty acids. Six-phase feeding was appliedstarter I (0-3 week), starter II (4-6 week), starter III (7-8 week), grower I (9-10 week), grower II (11-12 week) and finisher (13-16 week). The used compound feeds and
LALEV M., et al. nutritional composition during the different phases are shown in Table 1.

Growth performance was monitored by weeks $3,6,8,10,12,14$ and 16 by individual weighing of birds. At the end of each period, consumed and remaining feed were determined. Feed conversion was calculated by periods and for the entire duration of the study on the basis of feed intake and weight gain. The number of culled birds was registered on a daily basis.

For integral assessment of efficiency of replacement of sunflower oil in rations with Rümanol ML in compound feeds for turkey broilers, the European Poultry Efficiency Factor (EPEF) was calculated according to the formula:

$$
\mathrm{EPEF}=\frac{\text { live body weight }(\mathrm{kg}) \times \text { livability }(\%)}{\text { fattening period (days) } \times \text { feed conversion per } 1 \mathrm{~kg} \text { weight gain }} \times 100
$$

At 16 weeks of age, slaughter analysis was done on 3 birds from each group after 12-hour fasting. Birds had body weights close to the group average. Studied slaughter traits were slaughter weight, grill weight, breast weight (without bones and skin), leg weight (thigh and drumstick with bones and skin), wings weight, abdominal fat weight, liver, heart and gizzard weights. The relative weight of body parts from grill weight was calculated. Slaughter yield was determined as percentage ratio of grill without edible offal and slaughter weight.

Data were statistically processed by means of statistical software STATISTICA (Stat Soft inc.)

\section{RESULTS AND DISCUSSION}

At the beginning of the experiment, turkey poults from both groups had similar live weight, 51.83-51.91 $\mathrm{g}$ respectively. This parameter did not show any substantial changes during the early growth period and by 10 weeks of age, live weight was within the range $4109-4231$ g. Similar conclusions were reported by Jankowski et al. (15), namely that the effect of using various dietary lipid sources (soybean, rapeseed and flaxseed oils) on the live weight of turkeys could be observed after 63 days of age. By the end of the grower period (12 weeks of age), a statistically insignificant difference of $223.76 \mathrm{~g}(4.12 \%)$ in favour of the experimental group was recorded. During the finisher period, the supplementation of the diet of experimental turkey poults with Rümanol ML resulted in statistically significant increase of their body weight and by the end of the trial, the difference between groups was already 565.75 g $(7.13 \%)$ vs controls $(\mathrm{p}<0.001)$. With regard to the daily weight gain, there were no relevant differences during the first 10 weeks but during the subsequent periods, it was higher in experimental birds with greatest and statistically significant difference by $15-16$ weeks of age: $16.97 \%(p<0.05)$. Throughout the entire study, the weight gain of experimental turkey broilers was by $7.17 \%$ higher than that of controls $(\mathrm{p}<0.001)$.

The feed consumption for unit weight gain (Table 2) was similar to weight gain dynamics - close values until 10 weeks of age, then differences of $2.3 \%$, attaining $8.8 \%$ during the finisher period in favour of experimental birds, which could be attributed to the specific effect of dietary fat source. For the entire study period, feed conversion was by $2.5 \%$ better in experimental turkey poults than in controls. Smith et al. (19) did not demonstrate any effect of dietary fat source on feed consumption but reported an influence on the weight gain and feed conversion in broiler chickens. It is known that the degradation, absorption and conversion of feed depend on the time necessary for the feed to pass through the digestive tract (20) and in the view of Dänicke et al. (21) it depended on the dietary lipid source. The higher live weight of turkeys from the experimental group could be partly due to the better digestibility and absorption of 
nutrients as seen from the better feed conversion ratios. The positive effect of feed fat on growth performance could be attributed to the beneficial effect of this fat source on reduction of rate of feed passage through the digestive tract, hence more efficient utilization of nutrients. The analysis of data confirmed the results from a previous experiment with broiler chickens (22), showing statistically significant difference between live weights of groups at
LALEV M., et al. 35 and 49 days of age and higher values in birds fed rations with Rümanol ML. Therefore, the tested dietary fat source had a positive effect on the growth performance of hybrid turkey broilers. On the contrary, Fébel et al. (7) did not observe any considerable differences in the growth performance of broiler chickens fed compound feed with various oils as source of energy.

Table 2. Live weight, daily weight gain and feed conversion during the different age periods

\begin{tabular}{|c|c|c|}
\hline Parameters & $\begin{array}{l}\text { Control } \\
\text { group }\end{array}$ & $\begin{array}{l}\text { Experimental } \\
\text { group }\end{array}$ \\
\hline $\begin{array}{l}\text { Live weight of day-old } \\
\text { 0-3 weeks }\end{array}$ & 51.91 & 51.83 \\
\hline Live weight $(\mathrm{g})$ & 454.13 & 462.00 \\
\hline Daily weight gain $(\mathrm{g})$ & 19.15 & 19.53 \\
\hline Feed conversion $(\mathrm{kg} / \mathrm{kg})$ & 1.61 & 1.59 \\
\hline Livability $^{1}(\%)$ & 97.33 & 94.67 \\
\hline $\begin{array}{l}\text { 4-6 weeks } \\
\text { Live weight }(\mathrm{g}) \\
\text { Daily weight gain }(\mathrm{g}) \\
\text { Feed conversion }(\mathrm{kg} / \mathrm{kg}) \\
\text { Livability }(\%)\end{array}$ & $\begin{array}{l}1816.52 \\
64.88 \\
1.84 \\
94.67 \\
\end{array}$ & $\begin{array}{l}1839.02 \\
65.57 \\
1.86 \\
98.67 \\
\end{array}$ \\
\hline $\begin{array}{l}7-8 \text { weeks } \\
\text { Live weight }(\mathrm{g}) \\
\text { Daily weight gain }(\mathrm{g}) \\
\text { Feed conversion }(\mathrm{kg} / \mathrm{kg}) \\
\text { Livability }(\%)\end{array}$ & $\begin{array}{l}2938.26 \\
80.12 \\
2.56 \\
100 \\
\end{array}$ & $\begin{array}{l}3009.02 \\
83.57 \\
2.48 \\
98.67 \\
\end{array}$ \\
\hline $\begin{array}{l}\text { 9-10 weeks } \\
\text { Live weight }(\mathrm{g}) \\
\text { Daily weight gain }(\mathrm{g}) \\
\text { Feed conversion }(\mathrm{kg} / \mathrm{kg}) \\
\text { Livability }(\%)\end{array}$ & $\begin{array}{l}4108.70 \\
83.60 \\
2.74 \\
98.67 \\
\end{array}$ & $\begin{array}{l}4231.22 \\
87.30 \\
2.79 \\
100 \\
\end{array}$ \\
\hline $\begin{array}{l}\text { 11-12 weeks } \\
\text { Live weight }(\mathrm{g}) \\
\text { Daily weight gain }(\mathrm{g}) \\
\text { Feed conversion }(\mathrm{kg} / \mathrm{kg}) \\
\text { Livability }(\%)\end{array}$ & $\begin{array}{l}5434.78 \\
94.72 \\
3.01 \\
97.33\end{array}$ & $\begin{array}{l}5658.54 \\
101.95 \\
2.94 \\
100\end{array}$ \\
\hline $\begin{array}{l}\text { 13-14 weeks } \\
\text { Live weight }(\mathrm{g}) \\
\text { Daily weight gain }(\mathrm{g}) \\
\text { Feed conversion }(\mathrm{kg} / \mathrm{kg}) \\
\text { Livability }(\%)\end{array}$ & $\begin{array}{l}6713.04 \\
91.30 \\
3.52 \\
98.67 \\
\end{array}$ & $\begin{array}{l}7070.73^{*} \\
100.87 \\
3.33 \\
98.67 \\
\end{array}$ \\
\hline $\begin{array}{l}\text { 15-16 weeks } \\
\text { Live weight }(\mathrm{g}) \\
\text { Daily weight gain }(\mathrm{g}) \\
\text { Feed conversion }(\mathrm{kg} / \mathrm{kg}) \\
\text { Livability }(\%)\end{array}$ & $\begin{array}{l}7939.13 \\
87.58 \\
3.76 \\
98.67 \\
\end{array}$ & $\begin{array}{l}8504.88^{* * *} \\
102.44^{*} \\
3.43 \\
100\end{array}$ \\
\hline $\begin{array}{l}\text { 0-16 weeks } \\
\text { Daily weight gain }(\mathrm{g}) \\
\text { Feed conversion }(\mathrm{kg} / \mathrm{kg}) \\
\text { Livability }(\%)\end{array}$ & $\begin{array}{l}70.42 \\
2.83 \\
85.33\end{array}$ & $\begin{array}{l}75.47^{* * *} \\
2.76 \\
90.67\end{array}$ \\
\hline
\end{tabular}

$*$ - $\mathrm{p}<0.05 ; * * *$ - $<<0.001$

Livability $^{1}=100$ - Mortality rate for each period, $\%$ 
Livability is one of the important parameters in poultry farming. For the entire study period, higher livability percentage was demonstrated in experimental turkey broilers $(90.67 \%$ vs $85.33 \%$ in controls) - Table 2. Jankowski et al. (15) reported $2.1 \%$ to $3.5 \%$ mortality rates in hybrid turkeys fed diets with various vegetable oils with statistically insignificant between group differences. These values are lower than our results.
LALEV M., et al. The European Poultry Efficiency Factor was calculated for more objective evaluation of the tested product. It comprised the main factors influencing economic efficiency: live weight of turkeys at the end of the study, duration of rearing, feed consumption per $1 \mathrm{~kg}$ weight gain and livability. The analysis of EPEF data indicated higher values in the experimental group compared to the control by $16.64 \%$ (Table 3)

Table 3. European poultry efficiency factor (EPEF)

\begin{tabular}{|l|c|c|c|c|c|}
\hline \multirow{2}{*}{ Groups } & $\begin{array}{c}\text { Live weight at } 112 \\
\text { days of age, } \mathrm{Kg}\end{array}$ & Livability, \% & $\begin{array}{c}\text { Feed } \\
\text { conversion } \\
(\mathrm{kg} / \mathrm{kg})\end{array}$ & $\begin{array}{c}\text { Absolute } \\
\text { value }\end{array}$ & $\begin{array}{c}\% \text { vs } \\
\text { control } \\
\text { group }\end{array}$ \\
\hline Control & 7.94 & 85.33 & 2.83 & 213.76 & 100.00 \\
Experimental & 8.50 & 90.67 & 2.76 & 249.32 & 116.64 \\
\hline
\end{tabular}

The slaughter analysis (Table 4) showed statistically significantly higher grill weight (6928.67 g vs $6310.33 \mathrm{~g}$ ) and breast weight (2100 g vs $1904.33 \mathrm{~g}$ ) in experimental birds ( $<<0.05$ vs controls). Despite the established substantial differences in absolute values of these parameters, relative values did not differ significantly. The grill yield ranged from 79.21 - $81.35 \%$, while breast weight as a percentage of grill weight was almost the same in both groups, $30.17 \%$ and $30.31 \%$, respectively. As leg weight was concerned, experimental turkey broilers showed higher values but the difference of $5.8 \%$ was not statistically significant, e.g. only a trend was marked. In broiler chickens Abdulla et al (23) did not observe any effect of tested dietary energy sources on slaughter yield, breast and leg percentages from grill weight, but Mohammed and Horniakova (5) concluded that the combination of three fat sources in broiler chicken rations resulted in considerable increase in breast meat weight. Poorghasemi et al. (6) confirmed the positive influence of mixing dietary saturated and unsaturated fats not only on breast muscles, but on leg as well. In experiments with chickens fed rations with flaxseed, rapeseed and soybean oils, Hulan et al. (24) and Jankowski et al. (15) did not establish relevant differences in slaughter yield and breast, thigh and drumstick meat weights.

Table 4. Slaughter traits

\begin{tabular}{|l|l|l|}
\hline Parameters & $\begin{array}{l}\text { Control } \\
\text { group }\end{array}$ & $\begin{array}{l}\text { Experimental } \\
\text { group }\end{array}$ \\
\hline Slaughter weight (g) & 7966.67 & $8516.67^{*}$ \\
Grill weight (g) & 6310.33 & $6928.67^{*}$ \\
Slaughter yield (\%) & 79.21 & 81.35 \\
Breast (g) & 1904.33 & $2100.00^{*}$ \\
\% of grill weight & 30.17 & 30.31 \\
Legs (g) & 1789.33 & 1892.67 \\
\% of grill weight & 28.35 & 27.32 \\
Wings (g) & 778.67 & 769.00 \\
\% of grill weight & 12.35 & 11.10 \\
Abdominal fat $(\mathrm{g})$ & $58.00^{* *}$ & 31.67 \\
\% of grill weight & 0.92 & 0.46 \\
Liver (g) & 95.67 & 98.33 \\
Gizzard (g) & 95.00 & 99.00 \\
Heart (g) & 32.00 & 32.33 \\
\hline *-p p $<0.05$ & \multicolumn{2}{|l}{}
\end{tabular}


There were no substantial variations between the weight and relative proportion of wings from grill weight, the same was valid for leg percentage from grill weight. The absolute weights of liver, gizzard and heart in both groups were similar, within the normal ranges, confirming the absence of any negative impact of the tested feed fat. Nobakht et al. (1) and Poorghasemi et al. (6) showed no significant effect of dietary lipid source on relative weights of the liver, heart and gizzard in broiler chickens.

As abdominal fat was concerned, absolute weights of the two groups were considerably different $-31.67 \mathrm{~g}$ vs $58.00 \mathrm{~g}(\mathrm{p}<0.01)$, as did relative percentages from grill weight: $0.46 \%$ vs $0.92 \%(\mathrm{p}<0.05)$ in favour of the Rümanolsupplemented group. It is believed that the deposition of fat results from three main processes - absorption of dietary fat, de novo synthesis of endogenous fatty acids and fatty acids degradation - $\beta$-oxidation (25). In our study, the lower proportion of deposited abdominal fat in experimental birds was probably a result of the higher rate of oxidation and reduced rate of synthesis of fatty acids. Velasco et al. (26) reported greater abdominal fat deposition in broiler chickens fed rations supplemented with palm oil (rich in saturated fatty acids) compared to chickens fed diets containing sunflower oil (rich in polyunsaturated fatty acids).

\section{CONCLUSION}

The results from the experiment demonstrated that Rümanol ML used as alternative of dietary sunflower oil in turkey broilers feeds had a positive effect on the live weight during the finisher period and benefited feed conversion. Slaughter analysis showed higher absolute values of the grill and breast weights and no effect on slaughter yield and the share of valuable cuts (breast, legs, and wings) in experimental birds

The integral evaluation of replacing sunflower oil in compounds feeds for turkey poults with feed fat Rümanol ML on the basis of EPEF showed better performance by $16.64 \%$.

Based on the obtained results and the proven positive properties of Rümanol ML (low linoleic value, optimal balance between saturated and polyunsaturated fatty acids, stable physicochemical properties, heat resistance) we recommend to turkey producers to use the feed oil in quantities, reflected in
LALEV M., et al. the six age periods, which is consistent with their biological needs.

\section{REFERENCES}

1. Nobakht, A., Tabatbaei, S., Khodaei, S., Effects of different sources and levels of vegetable oils on performance, carcass traits and accumulation of vitamine in breast meat of broilers, Curr. Res. J. Biol. Sci, 3: 601-605, 2011.

2. Leeson, S. and J.O. Atteh, Utilization of fats and fatty acids by turkey poults. Poult. Sci., 74 (12): 2003-2010, 1995.

3. Tancharoenrat, P., Ravindran, V., Molan, A.L., Ravindran, G., Influence of fat source and Xylanase supplementation on performance, utilisation of energy and fat, and caecal microbiota counts in broiler starters fed wheat-based diets. Journal of Poultry Science 51: 172-179, 2014.

4. Balevi, T. and B. Coskun. Effects of some oils used in broiler rations on performance and fatty acid compositions in abdominal fat. Revue de Méd. Vét., 151, (10): 937-944, 2000.

5. Mohammed, H. A. and E. Horniakova. Effect of using saturated and unsaturated fats in broiler diet on carcass performance. Slovak J. Anim. Sci., 45,(1): 21-29, 2012.

6. Poorghasemi, M., Seidavi, A., Qotbi, A., Laudadio, V., Tufarelli, V., Influence of dietary fat source on growth performance responses and carcass traits of broiler chicks. Asian Australas. J. Anim. Sci., 26 (5): 705-710, 2013.

7. Febel, H., Mezes, M., Palfy, T., Herman, A., Gundel, J., Lugsi, A., Balogh, K., Kocsis, I., Blazovics, A., Effect of dietary acid pattern on growth, body fat composition and antioxidant parameters in broilers. J. Anim. Physiol. Anim. Nutr., 92: 369-376, 2008.

8. Kavouridou, K., Barroeta, A.C., Villaverde, C.E., Manzanilla, G., Baucells, M.D., Fatty acid, protein and energy gain of broilers fed different dietary vegetable oils. Spanish $J$. Agr. Res., 6: 210-218, 2008.

9. Delezie, E., Aerts ,J.M., Maertens, L., Huyghebaert, G., The efficiency of long chain n-3 fatty acid deposition of different dietary oils in turkeys at different ages. Arch. Geflügelk., 74: 51-57, 2010.

10. Mohammadi, Y; Yousefi, J; Kuhi, HD; Ahmadi, M., Effect of dietary saturated and unsaturated fats on body performance and accumulation of abdominal in broiler chickens. Iranian Journal of Applied Animal Science 1: 87-90, 2011. 
11.Pinchasov Y. and Nir I., Effect of dietary polyunsaturated fatty acid concentration on performance, fat deposition and carcass fatty acid composition in broiler chickens. Poult. Sci. 71: 1504-1512, 1992.

12.Zollitsch, W., Knaus, W., Aichinger, F., F.Lettner. Effects of different dietary fat sources on performance and carcass characteristics of broilers. Animal Feed Science and Technology, 66, 1-4: 63-73, 1997.

13.Sanz, M, Lopez-Bote, C.J., Monoyo, D., Bautista, J.M., Abdominal fat deposition and fatty acid synthesis are lower and floxidation is higher in broiler chickens fed diets containing unsaturated rather than saturated fat. J. Nutr.,130: 3034-3037, 2000.

14.Abas I., Ozpinar H., Kahraman R., Kutay H.C., Eseceli H. and Grashorn M.A., Effect of dietary fat sources and their levels on performance of broilers. Arch. Geflugelk. 68: 145-152, 2004.

15.Jankowski, J., Zduńczyk, P., Mikulski, D., Juśkiewicz, J., Mikulska ,M., Zduńczyk, Z., Effects of dietary soybean, rapeseed and linseed oils on performance, slaughter yield and fatty acid profile of breast meat in turkeys. J. Anim. Feed Sci., 21, 143-156, 2012.

16.Crespo, N. and Esteve-Garcia, E., Dietary fatty acid profile modifies abdominal fat deposition in broiler chickens. Poult. Sci., 80:71-78, 2001.

17.Crespo, N. and. Esteve-García, E., Dietary polyunsaturated fatty acids decrease fat deposition in separable fat depots but not in the remainder carcass. Poult. Sci., 81:512518, 2002

18.Ayed, H.B., Attia, H., Ennouri, M., Effect of Oil Supplemented Diet on Growth Performance and Meat Quality of Broiler Chickens. Adv. Tech. Biol. Med., 4:156, 2015

19.Smith M, Soisuvan K, Miller L., Evaluation of dietary calcium level and fat source on growth performance and mineral
LALEV M., et al. utilization of heat-distressed broilers. Poult. Sci., 2:32-37, 2003.

20.Rochell, S.J., Applegate, T.J., Kim, E.J., Dozier, W.A., Effects of diet type and ingredient composition on rate of passage and apparent ileal amino acid digestibility in broiler chicks. Poult. Sci., 91: 16471653, 2012.

21.Dänicke, S., Vahjen, W., Simon, O., Jeroch, H., Effects of dietary fat type and xylanase supplementation to rye-based broiler diets on selected bacterial groups adhering to the intestinal epithelium, on transit time of feed, and on nutrient digestibility. Poult. Sci., 78:1292-1299, 1999.

22.Lalev, M., Oblakova, M., Ribarski, S., Hristakieva, P., Mincheva, N., Ivanova, I., Effect of Rümanol ML vegetable oil on productivity of broiler chickens. I. Growth performance. Trakia Journal of Sciences, 1: 67-71, 2016.

23.Abdulla, N. R., Loh,T. C., Akit, H., Sazili,A.Q, Foo, H.L., Kareem,K.Y., Mohamad, R.,. Rahim, R.A., Effects of dietary oil sources, calcium and phosphorus levels on growth performance, carcass characteristics and bone quality of broiler chickens, Journal of Applied Animal Research, 45:1, 423-429, 2017.

24.Hulan, H., Proudfoot, F., Ackman, R., Ratnayake, W., Omega-3 fatty acid levels and performance of broiler chickens fed redfish meal or redfish oil. Can. J. Anim. Sci., 68:533-547, 1988.

25.Smink, W., Gerrits, W.J.J., Hovenier, R., Geelen, M.J.H., Verstegen, M.W.A., Beynen A.C., Effect of dietary fat sources on fatty acid deposition and lipid metabolism in broiler chickens. Poult. Sci., 89: 2432-2440, 2010.

26.Velasco, S., Ortiz, L.T., Alzueta, C., Rebole, A., Trevino, J., Rodriguez, M.L., Effect of inulin supplementation and dietary fat source on performance, blood serum metabolites, liver lipids, abdominal fat deposition and tissue fatty acid composition in broiler chickens. Poult. Sci., 89: 16511662, 2010. 